\title{
The Impact of Communication Between Teachers and Students: A Case Study of the Faculty of Management Sciences, University of Karachi, Pakistan
}

\author{
Dr. Zaeema Asrar \\ Assistant Professor, Department of Commerce, \\ University of Karachi, Pakistan \\ Noman Tariq \\ Hira Rashid \\ M.Phil. Scholar, Department of Commerce, \\ University of Karachi, Pakistan
}

Doi:10.19044/esj.2018.v14n16p32～URL:http://dx.doi.org/10.19044/esj.2018.v14n16p32

\begin{abstract}
Student's relationship with teachers is important because students spend about 7 to 9 hours a day and almost 11 months with the teacher. This paper focuses on ascertaining the impact of communication between teachers and students. Communication is a motivational tool for students to accomplish their studies. In this era, education is spreading very quickly all around the world. Universities are trying to improve their standard by increasing the quality of education as well as the quality of their students. This study examines the challenges which create barriers and huddles due to communication between the teachers and students to ensure that the students succeed. For this purpose, the faculty of management science, University of Karachi, Pakistan, was used as a case study. Its impact on students through the teacher's communication was examined. Three (3) departments are working under the faculty of management science. The random sampling method was used to gather the data from the departments. Descriptive analysis of mean and percentage were applied to find the impact of teacher's communication on the student's education and their success. The results show a positive relation between them. It is very difficult to create a positive relation between teachers and students when they get to a certain stage. This is because they are both mature, although it is necessary for both students and teachers. The qualities for a positive relationship can vary to make learning experience approachable and inviting for the students. If the teacher and the students have good communication skills and understand the importance of the impact of their communication, establishing a good relationship will be much easier. This research paper, however, shows that there is a positive relation between
\end{abstract}


teachers and students which creates goodwill for the teachers and makes the students to be result-oriented.

Keywords: Communication, students, teachers, education, skills, non-verbal, verbal

\section{Introduction}

Communication can be defined as a way of transferring thoughts and ideas to other people. Communication can either be verbal or non-verbal. Both ways of communication are very important for transferring thoughts. Teachers and students relation stand on the verbal and non-verbal means of communication. Communication is the blood of success in every walk of life. Effective communication plays an important role in building up the character and standard of student's education. Teacher's skills and ways of communication motivate the students to increase their ability in the field of education. Love, affection, sincerity, obligation, responsibility and dedication from the teacher may bring the prosperity and love which students require towards education. Therefore, many researches gave this idea towards this study. No other study that is related to University of Karachi, Pakistan, has been done in this context.

This brings us to the question; "what are the observations of a good student?" A greater amount of students go to universities and they have a favorite teacher by any means. A positive relation between teachers and students creates a healthy environment for good education. University is the stage where sensible and mature students obtain admission to grow their professional skills. Hence, a teacher serves as a role model to the students and he also creates goodwill from the perspective of the students. For a good environment, communication plays an important role in developing connection between students and teachers. A significant body of research indicates that academic achievement and student behavior are greatly influenced by the quality of the teacher and student relationship.

Teacher's non-verbal and verbal means of communication are reflected in the students' behavior, education, and ethics. Often times, it was observed that students are not quite relaxed in front of their teacher. Therefore, non-verbal communication from the teacher's side damages the character of students which might eventually result to depression. Communication does not just happen between two persons or more spontaneously, it is a gradual step that takes place continuously ( 24 hours a day and 7 days a week).

Consequently, courses and discipline of high standard cannot assess the quality of education. The quality can be assessed by the learning environment which gives a significant impact on the student's performance. The essential part of good learning environment is that the students feel 
pleasant and comfortable. This helps to improve the mental approach which in turn ultimately gives high returns in academics. For this purpose, it is necessary that faculty of universities should create a good positive relation with the students and improve their learning and communication skills. Therefore, this study shows the relation between student's performance and teacher's effective communication in the Faculty of Management Science, University of Karachi, Pakistan.

\section{Literature Review}

Good and effective communication can help well trained teacher to develop good relation with students (Richmond, 1990). Thus, there is more positive relation between teachers and students (Baruch, Hershkovitz \& P. Ang, 2015). Unavailability of teachers and poor communication by teachers are the major factors that have led students to abandon their study at a certain level (Dinu, 2015). Davis (2001) proved that the self-confidence and selfability of students helps to build their relationship with their teachers by nonverbal communication. Khan, et al. (2017) stated that the success of students is directly related to the effective communication of the teacher. Liberante (2012) opined that students and teacher relation have unlimited effect on learning, and it is very necessary for teachers to understand their students. A large amount of students agreed and thought that the friendly environment and cooperation of the teacher is an essential part of the success of the study. This research was done in Northern Boarder University, Saudi Arabia. Six different variables were examined and the result showed that a positive correlation was found. The friendly environment and non-verbal communication are correlated with the motivation of students. Subsequently, all these factors are important ingredients for achieving the study goals.

\section{Research Objectives}

The key objective of this study is to find out the main impact of the verbal and non-verbal communication of teachers on the students of Karachi University, Pakistan. It also aims to ascertain the outcomes of the communication for both (students and teachers). Therefore, the research aims: i. To find out if students are motivated by teacher's communication.

ii. To determine the impact of teacher's communication on students performance.

iii. To find out how much communication influences students' productivity.

\section{Research Hypotheses}

$\mathrm{H}_{\mathrm{o}}$ : No relation between effective communication and students' performance. 
$\mathrm{H}_{1}$ : There is a positive relation between teacher's motivation and students' performance.

$\mathrm{H}_{2}$ : There is a relationship between teacher's guidance and students' performance.

\section{Methodology}

\section{Research Design}

For the purpose of analyzing the hypothesis, descriptive survey method was used to find out the impact of effective communication on students. The descriptive survey deals with systematic description of an event in a very factual and accurate manner.

\section{The Study Area}

This study was carried out at the Management Science Department of the University of Karachi, Pakistan. Thus, it is one of the key faculties of the university. Under this faculty, three departments are performing their best in grooming the students for the field. Furthermore, this university is the largest university in Karachi and it is located at the center of the city. It is a public university and is well recognized all over Pakistan as well as across the globe.

\section{Sampling Techniques and Sample Size}

There are 3 departments under the management science faculty. These students belong to different study programs such as graduate, masters, master of philosophy, and doctorate program. Random sampling technique was applied to collect the desired data from the students.

\section{Research Instrument}

To collect the data for this research paper, questionnaire will be distributed. This questionnaire will consist of 10 questions which would be used to collect the data for the paper.

\section{Method of Data Analysis}

For the pool data analysis, descriptive statistical tool will be applied for analyzing the data. Frequency table, mean, median, standard deviation, and correlation are used for descriptive statistics.

\section{Research Instrument}

In this research, student's performance is the dependent variable while teacher's communication is the independent variable. For this purpose, a questionnaire which consists of 9 questions was developed and the data was collected from the students of the Faculty of Management Science. Data was collected from both male and female. 72 females and 41 males responded. 


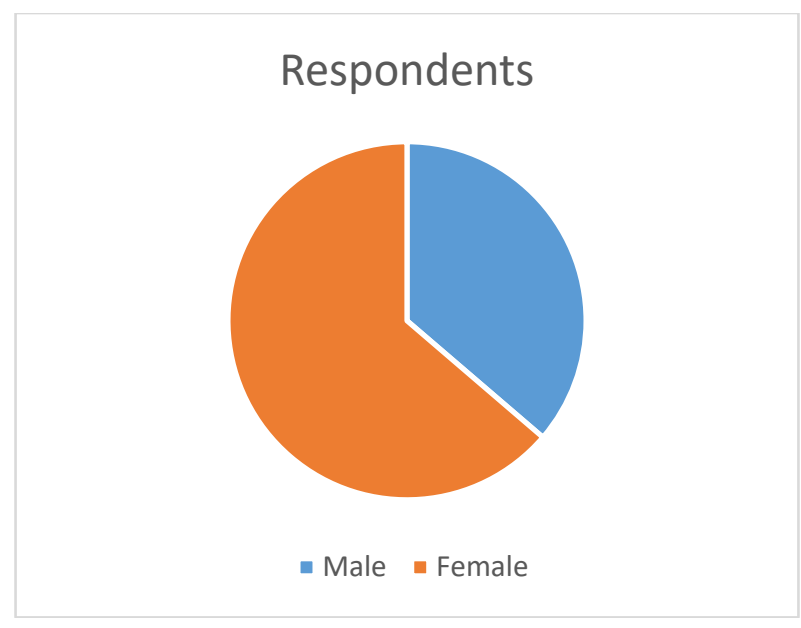

Figure 1. Respondents Chart

Consequently, the data was collected from 3 different department of the faculty of management science. The breakdown is given below:

Table 1. Data Collection form three (3) different departments

\begin{tabular}{ccccccc}
\hline Respondents & \multicolumn{2}{c}{ Male } & \multicolumn{2}{c}{ Female } & \multicolumn{2}{c}{ Sum } \\
\cline { 2 - 7 } Department & $\mathrm{N}$ & $\%$ & $\mathrm{~N}$ & $\%$ & $\mathrm{~N}$ & $\%$ \\
\hline Business School & 13 & 11.5 & 17 & 15 & 30 & 26.5 \\
\hline Public Administration & 11 & 9.7 & 29 & 25.7 & 40 & 35.4 \\
\hline Commerce & 17 & 15.1 & 26 & 23 & 43 & 38.1 \\
\hline Total & 41 & 36.3 & 72 & 63.7 & 113 & 100 \\
\hline
\end{tabular}

Questionnaire was developed on Likert scale of five-point answers. The options for respondents are $i=$ strongly agree, ii. Agree, iii. Neither agree nor disagree, iv. Disagree, v. Strongly disagree. 


\section{Results}

Table 2. Analysis of the result of the study

\begin{tabular}{|c|c|c|c|c|c|c|c|}
\hline & $\begin{array}{l}\text { Strongly } \\
\text { Agree }\end{array}$ & Agree & $\begin{array}{l}\text { Neither } \\
\text { agree nor } \\
\text { disagree }\end{array}$ & $\begin{array}{l}\text { Disagr } \\
\text { ee }\end{array}$ & $\begin{array}{l}\text { Strongly } \\
\text { disagree }\end{array}$ & Total & $\begin{array}{l}\text { Me } \\
\text { an }\end{array}$ \\
\hline & SA & A & $\mathrm{N}$ & DA & SDA & & \\
\hline $\begin{array}{l}\text { Your teacher's } \\
\text { nonverbal } \\
\text { communication is } \\
\text { good }\end{array}$ & $14 \%$ & $46 \%$ & $17 \%$ & $13 \%$ & $10 \%$ & $100 \%$ & 2.6 \\
\hline $\begin{array}{l}\text { Teacher's nonverbal } \\
\text { communication } \\
\text { affects the study }\end{array}$ & $15 \%$ & $57 \%$ & $19 \%$ & $7 \%$ & $2 \%$ & $100 \%$ & 2.2 \\
\hline $\begin{array}{c}\text { Teacher cooperates } \\
\text { with students }\end{array}$ & $16 \%$ & $40 \%$ & $19 \%$ & $15 \%$ & $10 \%$ & $100 \%$ & 2.6 \\
\hline $\begin{array}{c}\text { Teachers guides the } \\
\text { students }\end{array}$ & $21 \%$ & $38 \%$ & $18 \%$ & $13 \%$ & $11 \%$ & $100 \%$ & 2.6 \\
\hline $\begin{array}{c}\text { Teachers motivate } \\
\text { students in their } \\
\text { study }\end{array}$ & $21 \%$ & $40 \%$ & $23 \%$ & $11 \%$ & $5 \%$ & $100 \%$ & 2.4 \\
\hline $\begin{array}{l}\text { Students gets } \\
\text { motivation through } \\
\text { teacher's behavior }\end{array}$ & $34 \%$ & $36 \%$ & $9 \%$ & $16 \%$ & $5 \%$ & $100 \%$ & 2.2 \\
\hline $\begin{array}{c}\text { Students are } \\
\text { satisfied from } \\
\text { teacher's } \\
\text { communication } \\
\end{array}$ & $18 \%$ & $42 \%$ & $19 \%$ & $12 \%$ & $9 \%$ & $100 \%$ & 2.5 \\
\hline $\begin{array}{l}\text { Teacher increases } \\
\text { student's ability }\end{array}$ & $24 \%$ & $43 \%$ & $20 \%$ & $7 \%$ & $5 \%$ & $100 \%$ & 2.3 \\
\hline $\begin{array}{l}\text { Often times, teacher } \\
\text { uses abusive } \\
\text { language on } \\
\text { students }\end{array}$ & $3 \%$ & $8 \%$ & $5 \%$ & $46 \%$ & $38 \%$ & $100 \%$ & 4.1 \\
\hline $\begin{array}{l}\text { All teachers have } \\
\text { potential to teach }\end{array}$ & $19 \%$ & $33 \%$ & $17 \%$ & $18 \%$ & $14 \%$ & $100 \%$ & 2.8 \\
\hline
\end{tabular}

From the analysis of the questionnaire, different results were obtained regarding this paper. $57 \%$ of students with mean (2.6) agreed that the teacher's non-verbal communication is the most important, and it plays a crucial role in the performance of the students' study. Their perception is that the non-verbal communication of their teachers is an important tool for engaging them in their studies.

$40 \%$ of students with mean (2.4) agreed that motivation is the key factor from the teacher's perspective, which encourages the students to achieve high score. $36 \%$ of the students agreed that they are motivated from teacher's non-verbal communication. Students are satisfied with their teachers as long as they guide them in their studies and help them when they are faced with difficulties. $43 \%$ of students with mean (2.3) agreed that their teachers have the ability to 
increase their abilities and this is achieved as they employ the use of different techniques for boosting their skills.

Table 3. Respondents Enrollment in University

\begin{tabular}{|l|l|l|}
\hline Education level & No. of students & $\%$ \\
\hline 14 & 20 & 18 \\
\hline 16 & 72 & 64 \\
\hline 18 & 12 & 11 \\
\hline 21 & 8 & 7 \\
\hline Total & 112 & 100.00 \\
\hline
\end{tabular}

Respondent enroll in University of Karachi $11 \%$ $7 \% 18 \%$

Figure 2. Respondent enroll in University of Karachi

\section{Conclusion}

In conclusion, communication plays a very crucial role in building up the career of students. The communication of teachers, either verbal or nonverbal, is an important factor required by students to become successful in their educational pursuit. Communication motivates the students to enhance their abilities. It also encourages the students to work hard. Therefore, it is very important and necessary that the teachers should communicate with students in an effective manner. Departments should observe the key factor for enhancing the ability of students through different channels of communication.

\section{References:}

1. A.Davis Heather (2001). "The Quality and Impact of Relationships between Elementary School Students and Teachers." Contemporary Educational Psychology.

2. Baruch Alona Forkosh, Arnon Hershkovitz, \& Rebecca P. Ang. (2015). "Teacher-student Relationship and SNS-mediated 
Communication: Perceptions of both Role-players." Interdisciplinary Journal of e-Skills and Lifelong Learning.

3. Dinu Bajracharya (2015). "Impact of Teacher-Student Communication on "High-Risk." Developing Country Studies.

4. Khan Alamgir, Dr Salahuddin Khan, Syed Zia-Ul-Islam, \& Manzoor Khan (2017). "Communication Skills of a Teacher and Its Role in the Development of the Students' Academic Success." Journal of Education and Practice.

5. Liberante Lauren (2012). "The importance of teacher-student relationships, as explored through the lens of the NSW Quality Teaching Model." Journal of Student Engagement: Education Matters.

6. L. Cayanus Jacob, Matthew M. Martin, \& Alan K Goodboy (2009). "The Relation Between Teacher Self-Disclosure and Student Motives to Communicate." Communication Research Reports.

7. Richmond virginia, P. (1990). "communication in the class room: power and motivation." communication education. 